\title{
Lingkungan dalam Pembelajaran Bahasa Indonesia
}

Lingkungan hidup merupakan bagaian dari bumi yang mencakup makhluk hidup seperti manusia, tumbuhan, dan hewan serta benda lainnya seperti air, tanah, udara ataupun sumber energi yang ada didalamnya dan menjadi satu. Menurut Mitsuki dan Lai (dalam Ramadhan et al, 2019), di seluruh dunia, semua orang menghadapi masalah lingkungan yang serius, seperti pemanasan global, hujan asam, ozon perusakan lapisan, pencemaran lingkungan, kerusakan alam, dan hilangnya keanekaragaman hayati yang bisa serius mengancam kehidupan generasi saat ini, terutama generasi masa depan. Kondisi lingkungan yang sungguh memprihatinkan dan dari waktu ke waktu terus mengalami penurunan, serta gejala-gejala alam yang menunjukkan hal itu telah nampak semakin jelas. Semakin tingginya suhu bumi dan musim yang sulit untuk diprediksi merupakan contoh gejala yang kita rasakan dari semakin rusaknya lingkungan bumi.

Pencemaran terhadap lingkungan hidup sejatinya berasal dari manusia sendiri yang telah mencemari air, tanah dan udara sehingga fenomena ini kita kenal sebagai fenomena pemanasan global (global warming). Menurut Lai dan Uttara (dalam Ramadhan et al, 2019), kerusakan lingkungan menghasilkan krisis ekologis yang akan menyebabkan serangkaian masalah dengan alam sumber daya, iklim, polusi, makanan, dan ekonomi. Menurut Kibbe (dalam Ramadhan et al, 2019), ini karena lingkungan menentukan dinamika kehidupan, kesehatan masyarakat, perkembangan spiritual dan moral . Untuk itu diperlukan kesadaran individu dan tanggung jawab terhadap lingkungan.

Lai (dalam Ramadhan et al, 2019), mengatakan masalah lingkungan secara inheren tidak dapat dipisahkan dari kesadaran lingkungan, nilai-nilai, dan sikap orang. Ini mendorong negara untuk mulai menilai pendidikan lingkungan. Dengan pendidikan yang baik seseorang akan lebih mampu berfikir banyak hal dan mempunyai wawasan yang luas sehingga dalam bersikap dan bertingkah laku tentunya mereka akan lebih tertata. Menurut Jacobs dan Cates (dalam Ramadhan et al, 2019), tujuan dari pendidikan lingkungan adalah untuk membuat siswa berpartisipasi dalam melindungi lingkungan. Menurut Paterson (dalam Ramadhan et al, 2019), yayasan Pendidikan Lingkungan Nasional menjelaskan tiga tingkat lingkungan pendidikan yang dijelaskan di bawah ini. Pertama, yaitu kesadaran lingkungan, keakraban umum dengan kunci isu yang berkaitan dengan lingkungan. Kedua, pengetahuan tentang perilaku pribadi, yang menerjemahkan 
kesadaran menjadi tindakan untuk melestarikan lingkungan. Ketiga, literasi lingkungan, yang memungkinkan siswa untuk belajar prinsip-prinsip dasar dan memperoleh keterampilan untuk melaksanakan proyek mereka sendiri.

Hauchild (dalam Ramadhan et al, 2019), mengatakan guru bahasa berada di posisi unik untuk mempromosikan kesadaran lingkungan. Guru bahasa memainkan peran penting dalam mengintegrasikan pendidikan lingkungan. Menurut Hauchild (dalam Ramadhan et al, 2019), dengan mengintegrasikan pendidikan lingkungan ke dalam kelas bahasa, pendidik dapat meningkatkan minat siswa masalah kontemporer yang mungkin secara langsung mempengaruhi masa depan mereka; ajari siswa bagaimana berkontribusi pada dunia yang lebih sehat dan lebih berkelanjutan; dan mempromosikan pembelajaran bahasa yang bermakna dan komunikasi.

Hasil penelitian tentang pengaruh materi pendidikan lingkungan pada pembelajaran Bahasa Indonesia, dari 39 responden 29 siswa (66,7\%) sangat setuju, 12 siswa (30,8\%) setuju, dan 1 siswa $(2,6 \%)$ tidak setuju jika guru memberikan pemahaman kepada saya tentang menumbuhkan sikap kesadaran dan peduli terhadap lingkungan. 20 siswa (51,3\%) sangat setuju, 18 siswa $(46,2 \%)$ setuju, dan 1 siswa $(2,6 \%)$ tidak setuju jika berpartisipasi dalam melindungi lingkungan. 9 siswa $(23,1 \%)$ sangat setuju, 27 siswa $(69,2 \%)$ setuju, dan 3 siswa $(7,7 \%)$ tidak setuju bahwa mereka memiliki pengalaman tentang masalah lingkungan. 20 siswa $(51,3 \%)$ sangat setuju, 17 siswa $(43,6 \%)$ setuju, dan 2 siswa $(5,1 \%)$ tidak setuju jika pada pembelajaran Bahasa Indonesia guru menggunakan tema tentang lingkungan dala pembelajaran berbasis teks. 17 siswa $(43,65 \%)$ sangat setuju, 20 siswa (51,3\%) setuju, dan 2 siswa $(5,1 \%)$ tidak setuju jika materi tentang lingkungan dapat mempengaruhi sikap dan kepedulian terhadap lingkungan. 22 siswa $(56,4 \%)$ menyatakan sangat setuju dan 17 siswa $(43,6 \%)$ setuju bahwa guru mampu menyadarkan siswa tentang pentingnya menjaga lingkungan. 15 siswa (38,5\%) sangat setuju, 21 siswa $(53,8 \%)$ setuju, dan 3 siswa $(7,7 \%)$ tidak setuju bahwa dalam pembelajaran siswa tertarik menggunakan media lingkungan tentang kerusakan lingkungan dan mitigasi bencana dalam pembelajaran bahasa. 13 siswa $(33,3 \%)$ sangat setuju, 20 siswa $(51,3 \%)$ setuju, dan 6 siswa $(15,4 \%)$ tidak setuju bahwa siswa mampu membuat cerita pendek tentang pentingnya menjaga lingkungan. 10 siswa (25,6\%) sangat setuju, 28 siswa (71,8\%) setuju, dan 1 siswa $(2,6 \%)$ tidak setuju jika memberikan tanggapan dalam diskusi tentang berita bencana alam pada pembelajaran 
Bahasa Indonesia. 26 siswa (66.7\%) sangat setuju, 12 siswa (30,8\%) setuju, dan 1 siswa (2,6\%) tidak setuju jika melihat sampah maka diambil dan dimasukkan ke tempat sampah.

Berdasarkan hasil penelitian dan kajian yang dilakukan penulis, dapat disimpulkan bahwa masih ada siswa yang tidak peduli pentingnya menjaga lingkungan. Padahal setiap siswa memiliki peran dan tanggung jawab untuk peduli dan mau melindungi lingkungan. Untuk itu guru memainkan peran penting dalam menyampaikan pengetahuan ini kepada siswa, karena siswa adalah generasi yang bertugas melindungi dan menjaga lingkungan. Guru harus dapat merancang pembelajaran bahasa dengan mengintegrasikan topik tentang pendidikan lingkungan semenarik mungkin, sehingga bisa membangkitkan kesadaran siswa akan pentingnya menjaga dan melindungi lingkungan. 


\section{Daftar Rujukan}

Ramadhan, S., Sukma, E., \& Indriyani, V. (2019). Environmental education and disaster mitigation through language learning. IOP Conference Series: Earth and Environmental Science 314, pp. 1-9. 